\title{
Phylogenetic analysis of American hop latent virus in Humulus lupulus surveyed in Tasmania and Victoria, Australia
}

\author{
Alison L. Dann • Shane E. Hössel • Peter A. Cross • \\ Simon P. Whittock
}

Received: 2 April 2014 / Accepted: 16 July 2014 / Published online: 25 July 2014

(C) Australasian Plant Pathology Society Inc. 2014

\begin{abstract}
During July to August 2013 hop (Humulus lupulus) buds growing in Tasmania $(n=280)$ and Victoria $(n=200)$ from nine varieties were sampled and tested for the presence of American hop latent virus (AHLV) by enzyme linked immunosorbent assay and reverse transcription polymerase chain reaction using coat protein gene specific primers. Immunological results showed 153/480 bud samples were positive. RT-PCR resulted in an additional 19 positive samples. Coat protein gene sequence analysis showed 98-99 \% identity with AHLV isolates from the USA.
\end{abstract}

Keywords American hop latent virus · Humulus lupulus . RT-PCR · DAS-ELISA

Hop (Humulus lupulus) has been grown in Tasmania and Victoria for over a 100 years as the day-length, winter temperature, water and soil suited the crop. Hop is grown predominantly for its resins, essential oils and polyphenols that impart bitterness and aroma to beer. The natural chemistry of interest to brewers accumulates in glandular trichomes that develop in the cones (strobiles), which constitute the harvest crop. Viruses

\footnotetext{
A. L. Dann $(\bowtie) \cdot$ S. E. Hössel · P. A. Cross

Department of Primary Industries, Parks, Water and Environment, Biosecurity and Product Integrity Division, 13 St Johns Avenue, New Town, TAS 7008, Australia

e-mail: Alison.Dann@dpipwe.tas.gov.au

S. P. Whittock

Hop Products Australia Limited, 26 Cambridge Road, Bellerive,

TAS 7018, Australia
}

and viroids pose significant constraints to production yields of hop cultivars around the world. In Australia the main virus and viroid pathogens found in hop are the Carlaviruses Hop latent virus (HpLV), Hop mosaic virus (HpMV) and the Ilarvirus Apple mosaic virus (ApMV), the Nepovirus Arabis mosaic virus (ArMV), Prune necrotic ring spot virus (PNRSV) and Hop Latent viroid (HLVd) (Munro 1987; Pethybridge et al. 2000).

American hop latent virus (AHLV), a member of the genus Carlavirus, was first discovered by Probasco and Skotland (1976) and described by Adams and Barbara (1982). This virus is common in the USA and has been found in England, West Germany (Barbara and Adams 1983) and New Zealand (Hay et al. 1992). It has previously only been detected in material of North American origin in post-entry quarantine in Australia and the plants were subsequently destroyed (Munro 1987). It has been found in the USA that AHLV generally occurs at a lower frequency than the other carlaviruses (Pethybridge et al. 2002).

AHLV is only remotely serologically related to other hop carlaviruses. Eastwell and Druffel (2012) found the predicted coat protein (CP) sequences of HpMV and HpLV shared only 37 and $38 \%$ identity to AHLV respectively. The hop-damson aphid, Phorodon humuli, is the most important vector for hop carlaviruses; however, this aphid has not been found in Australia. Vectors in Australia include the potato aphid (Macrosiphum euphoria) and green peach aphid (Myzus persicae) both of which were found to transmit HpLV and HpMV (Crowle et al. 2006). A survey of aphid species in Tasmanian hop gardens was conducted by Pethybridge et al. (2004) and related to HpLV and HpMV infections over several seasons and found aphids would be 
important for new points of infection. However, mechanical inoculation and/or root grafting are probably more significant means of transmission for these viruses in Tasmania (Pethybridge et al. 2008).

During July to August 2013 a survey of 480 hop buds from 4 varieties grown in Bushy Park, Tasmania $(n=280$ and 7 varieties grown in Eurobin, Victoria $(n=$ 200) (Table 1) was performed using double-antibody sandwich enzyme linked immunosorbent assay (DASELISA) (in-house antisera). 153 (32\%) bud samples gave positive results for AHLV. A subset of samples (182) that had borderline DAS-ELISA results had RNA extracted using the PowerPlant ${ }^{\circledR}$ RNA Isolation Kit with DNase (Mobio Laboratories Inc., Solana Beach California, USA. These were tested using one-step reverse transcription polymerase chain reaction (RT$\mathrm{PCR}$ ) using primers specific for the $\mathrm{CP}$ gene AHLVcpF (5'-ATGTCGAACGTTGAAAGG-3') and AHLVcpR (5'-TCAGTGCGCTTGTCGAAACTC-3') (Eastwell and Druffel 2012). The PCR was performed using Qiagen OneStep RT-PCR kit (Qiagen, Valencia, California, USA) according to the manufacturer's protocol with an annealing temperature of $56{ }^{\circ} \mathrm{C}$ for 35 cycles. RT-PCR gave an additional 19 positive results, hence the overall total of positive plants for AHLV was $172 / 480$ ( $\sim 36 \%)$. The amplicons ( $970 \mathrm{bp})$ from 14 representative samples were purified using the UltraClean ${ }^{\circledR}$ GelSpin ${ }^{\circledR}$ DNA Extraction Kit (Mobio) and sequenced using the same primers at the Australian Genome Research Facility (AGRF). Coat protein gene sequences were edited using ChromasPro 1.7.5 (2012). Sequences were submitted to GenBank and accession numbers are KF749271-KF749280 and KF964321KF964324 (Fig. 1). Representative samples were also sent to the Victorian Plant Pathology Herbarium (VPRI) accession numbers VPRI42340-VPRI42349 and details entered into the Australian Plant Pest Database (APPD).

NCBI BLAST analysis showed 98-99 \% identity at nucleotide level and 91-92 \% identity at predicted amino acid (aa) level to AHLV isolates in GenBank (from hop varieties Bittergold and Galena, accessions JQ245696 and JQ728538 respectively). Phylogenetic analysis (MEGA v5.2.2, (Tamura et al. 2011)) of the predicted aa sequences with 28 representative and tentative carlavirus predicted aa sequences from GenBank showed that all Victorian and Tasmanian isolates clustered with the two known AHLV isolates ("Bittergold" and "Galena") which share $98 \%$ aa identity (Eastwell and Druffel 2012) in the Carlavirus clade I and were only distantly related to the other Carlaviruses that infect hops in the Carlavirus clade II (Adams et al. 2005) (Fig 1). This is also the first report of AHLV infecting $H$. lupulus grown in Tasmania and Victoria, Australia; however, this virus has probably been established for quite some time.
Table 1 Hop bud survey results for AHLV in Victoria and Tasmania by variety and location by ELISA and RT-PCR. RT-PCR positives are additional positive results for AHLV as they were from very weak positives to negative AHLV samples from ELISA

\begin{tabular}{|c|c|c|c|c|c|}
\hline \multirow[t]{2}{*}{ State } & \multirow[t]{2}{*}{ Variety } & \multirow[t]{2}{*}{ No. Sampled } & \multirow[t]{2}{*}{ Location } & \multicolumn{2}{|c|}{ AHLV positive results } \\
\hline & & & & ELISA & PCR \\
\hline \multirow[t]{9}{*}{ Victoria } & Super & 6 & Nursery & 1 & \\
\hline & Topaz & 6 & Nursery & 2 & 1 \\
\hline & Galaxy & 6 & Nursery & 0 & \\
\hline & Ella & 111 & Experimental Garden & 42 & 6 \\
\hline & Vic Secret & 51 & Nursery/Experimental Garden & 0 & \\
\hline & 04-337-016 & 5 & Experimental Garden & 2 & 1 \\
\hline & $03-277-033$ & 15 & Experimental Garden & 8 & 3 \\
\hline & Total sampled & 200 & Total & 55 & 11 \\
\hline & \multicolumn{3}{|c|}{ Additional positive from PCR } & & 2 \\
\hline \multirow[t]{8}{*}{ Tasmania } & Galaxy & 40 & Nursery & 1 & 1 \\
\hline & Ella & 200 & Nursery & 97 & 16 \\
\hline & $98-213-035$ & 20 & Nursery/Experimental Garden & 0 & \\
\hline & Cascade & 20 & Nursery & 0 & \\
\hline & Total sampled & 280 & Total & 98 & 17 \\
\hline & \multicolumn{3}{|c|}{ Additional positive from PCR } & & 17 \\
\hline & & & & 115 & \\
\hline & Total & 480 & Total positive (ELISA+PCR) & 172 & \\
\hline
\end{tabular}


Fig. 1 Neighbor-Joining phylogenetic tree of predicted amino acid sequences of 14 AHLV isolates from Victoria (VIC) and Tasmania (TAS), Australia. The tree was generated using the Poisson correction model, 100 bootstrap replications, pairwise gap deletion and a uniform rate of evolution (MEGA v5.2.2). Representative and tentative (t) carlavirus species were used for comparison. The viruses used were Aconitum latent virus $(A c L V)$, American hop latent virus $(A H L V)$, Blueberry scorch virus $(B l S c V)$, Butterbur mosaic virus (ButMV), Chrysanthemum virus B $(C V B)$, Cole latent virus $(C L V)$, Coleus vein necrosis virus $(C V N V)$, Cowpea mild mottle virus $(C M M V)$, Daphne virus S $(D V S)$, Garlic common latent virus (GarCLV), Hop latent virus (HpLV), Hop mosaic virus (HpMV), Hydrangea chlorotic mottle virus (HdChMV),

Kalanchoe latent virus $(K L V)$, Lily symptomless virus $(L S V)$, Mirabilis jalapa mottle virus $(M j M V)$, Narcissus common latent virus (NCLV), Narcissus symptomless virus (NSV), Passiflora latent carlavirus (PLCV), Phlox virus S (PhlVS), Poplar mosaic virus (PopMV), Potato latent virus (Pot $L V$ ), Potato virus $\mathrm{M}(P V M)$, Potato virus $\mathrm{P}$ $(P V P)$, Potato virus $\mathrm{S}(P V S)$, Red clover vein mosaic virus $(R C V M V)$, Sweet potato chlorotic fleck virus $(S P C F V)$. Apple stem pitting virus $(A S P V)$ was used as the out-group. Scale bar is number of amino acid substitutions per site. Clade grouping from Adams et al. (2005)

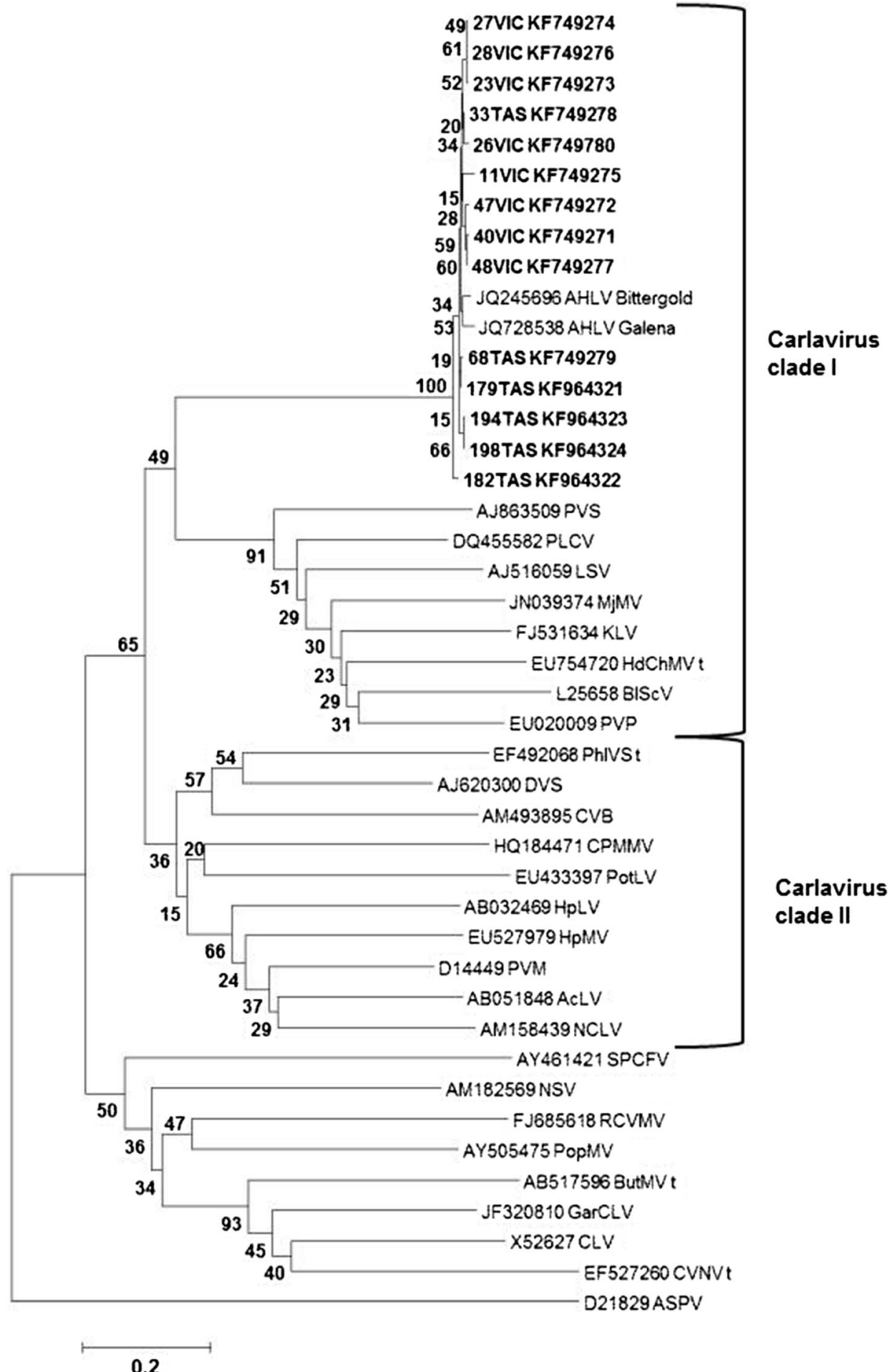

\section{References}

Adams AN, Barbara DJ (1982) Host range, purification and some properties of two carlaviruses from hop (Humulus lupulus): hop latent and American hop latent. Ann Appl Biol 101(3):483-494
Adams MJ, Accotto GP, Agranovsky AA, Bar-Joseph M, Boscia D, Brunt AA, Candresse T, Coutts RHA, Dolja VV, Falk BW, Foster GD, Gonsalves D, Jelkmann W, Karasev A, Martelli GP, Mawassi M, Milne RG, Minafra A, Namba SAR, Vetten HJ, Vishnichenko VK, Wisler GC, Yoshikawa N, Zavriev SK (2005) Family flexiviridae. In: Fauquet CM, Mayo MA, Maniloff J, Desselberger 
U, Ball LA (eds) Virus taxonomy: the eight report of the international committee on the taxonomy of viruses. Elsiever Academic Press, San Diego

Barbara DJ, Adams AN (1983) American hop latent virus. CMI/AAB Descriptions of Plant Viruses No. 262

ChromasPro 1.7.5 (2012) Technelysium Pty Ltd, South Brisbane, Queensland, Australia

Crowle DR, Pethybridge SJ, Wilson CR (2006) Transmission of hop latent and hop mosaic carlaviruses by Macrosiphum euphorbiae and Myzus persicae. J Phytopathol 154(11-12):745-747

Eastwell KC, Druffel KL (2012) Complete genome organization of American hop latent virus and its relationship to carlaviruses. Arch Virol 157(7):1403-1406

Hay FS, Close RC, Hetcher JD, Ashby JW (1992) Incidence and spread of viruses in hop (Humulus lupulus L.) in New Zealand. N Z J Crop Hortic Sci 20(3):319-327

Munro D (1987) Viruses infecting hop, Humulus lupulus, in Australia. Aust J Agric Res 38:83-90

Pethybridge SJ, Wilson CR, Sherriff LJ, Leggett GW, Munro D (2000) Virus incidence in Australian hop (Humulus lupulus L.) gardens and cultivar differences in susceptibility to infection. Aust J Agric Res 51(6):685-689

Pethybridge SJ, Nelson ME, Eastwell KC, Klein RE, Kenny ST, Wilson CR (2002) Incidence and spatial distribution of viruses in hop gardens of Washington state. Plant Dis 86(6): 661-665

Pethybridge SJ, Madden LV, Griggs J, Wilson CR (2004) Species composition and abundance of aphids in Australian hop gardens and their impact on spatiotemporal patterns of Carlavirus epidemics. Plant Pathol 53(4):498-507

Pethybridge SJ, Hay FS, Barbara DJ, Eastwell KC, Wilson CR (2008) Viruses and viroids infecting hop: significance, epidemiology, and management. Plant Dis 92(3):324-338

Probasco EG, Skotland CB (1976) The isolation of a line-pattern and ringspot producing rod-shaped virus from hops. Proc Am Phytopathol Soc 3:319-320

Tamura K, Peterson D, Peterson N, Stecher G, Nei M, Kumar S (2011) MEGA5: molecular evolutionary genetics analysis using maximum likelihood, evolutionary distance, and maximum parsimony method. Mol Biol Evol 28:2731-2739 